\title{
Analysis of Sagunto Ibero-Roman votive bronze statuettes by portable X-ray fluorescence
}

\author{
Sonia Rubio-Barberáa ${ }^{a}$ Javier Fragoso ${ }^{\mathrm{a}}$, Gianni Gallello ${ }^{\mathrm{a}, \mathrm{b}, *},{\text { Ferran } \text { Arasa }^{\mathrm{c}} \text {, Marco Lezzerini }}^{\mathrm{d}, \mathrm{e}}$, \\ Emilia Hernández ${ }^{\mathrm{f}}$, Agustín Pastor ${ }^{\mathrm{a}}$, Miguel de la Guardia ${ }^{\mathrm{a}}$ \\ a Department of Analytical Chemistry, University of Valencia, C/Dr. Moliner 50, 46100 Burjassot, Valencia, Spain \\ ${ }^{\mathrm{b}}$ Department of Archaeology, University of York, King's Manor, YO17EP York, UK \\ ${ }^{\mathrm{c}}$ Department of Prehistory, Archaeology and Ancient History, Faculty of Geography and History University of Valencia, Av. Blasco Ibáñez, 28, 46010 Valencia, Spain \\ ${ }^{\mathrm{d}}$ Department of Earth Sciences, University of Pisa, Via S. Maria 53, 56126 Pisa, Italy \\ e Applied and Laser Spectroscopy Lab., ICCOM-CNR, Via G. Moruzzi 1, 56124 Pisa, Italy \\ ${ }^{\mathrm{f}}$ Sagunto Archaeological Museum, C/del Castillo 23, 46500 Sagunto, Valencia, Spain
}

\section{A R T I C L E I N F O}

\section{Keywords:}

pXRF

Bronze statuettes

Ibero-Roman

Sagunto

Metals provenance

\begin{abstract}
A B S T R A C T
The main objective of this work was the study of chemical composition of an important collection of IberoRoman votive bronze statuettes exposed in the Archaeological Museum of Sagunto (Spain). Precision and accuracy of the measurements were obtained developing a proper analytical method, also avoiding any possible damage to the studied objects using a portable energy dispersive $\mathrm{X}$ - ray fluorescence system.

Principal Components Analysis (PCA) to discriminate between groups based on ratios $\mathrm{Fe} / \mathrm{Cu}, \mathrm{Pb} / \mathrm{Cu}, \mathrm{Sn} / \mathrm{Cu}$, $\mathrm{Ag} / \mathrm{Cu}, \mathrm{Ni} / \mathrm{Cu}$ and Impurities/Cu were employed to observe differences between the used smelting, manufacturing processes and raw materials. The characterisation of bronze statuettes cross-referenced with archaeological data, gave important suggestions to clarify issues regarding manufacturing processes, quality and chronologies of the studied objects.
\end{abstract}

\section{Introduction}

The study of archaeological bronze objects has consistently advanced in the last decades and, nowadays, a large number of results are available, especially concerning their composition and corrosion layers (Robbiola et al., 1998; Neff et al., 2013; Vasiliev et al., 2016), their manufacturing, authenticity and fabrication technology (Dungworth, 1997; Klemenc et al., 1999; Smith et al., 2011; Scott, 2013; Scuotto et al., 2014; Sorrentino et al., 2015), together with information about raw material provenance (Ferretti et al., 2007; Baldassarri et al., 2014).

However, the great challenges for archaeological bronze studies are related to the difficulties to carry out exhaustive analyses due to their historical and artistic relevance. This limits the access to the objects, and the employment of destructive analytical methods to isolated cases. For example, Klemenc et al. (1999) carried out minor element analyses by inductively coupled plasma atomic emission spectrometry (ICP-AES) to evaluate the manufacturing process and the influence of the impurities in provenance studies of plano-convex ingots from seven late Slovenian Bronze Age hoards. As an alternative to ICP, techniques that damage the samples at micrometric levels such as scanning electron microscopy (SEM), transmission electron microscopy (TEM), energydispersive X-ray microanalysis (EDXMA), X-ray diffraction (XRD), scanning electron microscopy (SEM) and laser induced breakdown spectroscopy (LIBS) have been employed for ancient metal studies. Vasiliev et al. (2016) preferred SEM, TEM and EDXMA to determinate fabrication processes in axes and arrows of copper. XRD and SEM were employed to study slag samples from furnaces to understand the smelting and manufacturing processes of copper (Sáez et al., 2003). The determination of copper coins by LIBS was carried out to stablish differences in the use of raw materials (Bachler et al., 2016). Therefore, the improvement of portable and non-destructive analytical methodologies becomes necessary to chemically characterize archaeological metal objects.

The development of portable energy dispersive X-ray fluorescence (pEDXRF) allowed to carry out fast, green, low cost and direct analysis, without causing any damage to the measured materials. The pEDXRF is perfectly compatible with the analysis of archaeological remains as sediments, ceramic, rocks (Forster et al., 2011; Hunt and Speakman, 2015; Gallello et al., 2016; Grave et al., 2012; Grau Mira, Gallello, 2017), as well as with studies of Roman, Iberian and Phenician bronze

\footnotetext{
* Corresponding author at: Department of Analytical Chemistry, University of Valencia, C/Dr. Moliner 50, 46100 Burjassot, Valencia, Spain.

E-mail address: gianni.gallello@york.ac.uk (G. Gallello).
} 
statues (Ferretti et al., 2007; Schiavon et al., 2013; Roldán García and Vives-Ferrándiz Sánchez, 2018).

Nevertheless, the limitations of XRF devices are related to the low sensitivity, high limits of detection, and difficulties to obtain reproducible results from heterogeneous samples, together with the limitations to obtain spectra from low atomic weight elements (Karydas, 2007; Speakman and Shackley, 2013).

Additional limitations of the mentioned technique are related with size, irregular surface, heterogeneity, fragility and the presence of modified layers due to post-depositional processes affecting archaeological metal objects like bronzes. Further difficulties may be related to the access to objects preserved under special conservation conditions. Therefore, a correct analysis by pEDXRF needs to be carried out on a flat surface, because an irregular or corroded surface can affect the intensity of the excitation and emitted radiation and this could modify the accuracy of results (Liangquan et al., 1998; Navas et al., 2016; Roldán García and Vives-Ferrándiz Sánchez, 2018; Schiavon et al., 2016).

The main objective of this work was the study of metal composition of an important collection of Ibero-Roman votive bronze statuettes exposed in the Archaeological Museum of Sagunto (Spain). To do it, a validated XRF method was developed after verification of precision and accuracy of measurements obtained with a portable energy dispersive $\mathrm{X}$-ray fluorescence system, which ensure to avoid any damage to the statuettes.

Additionally, the chemical characterisation of votive bronzes offers the possibility to assess the provenance of the statuettes, employing Principal Components Analysis (PCA) to discriminate between groups based on metal composition and relationship between elements, such as $\mathrm{Cu}, \mathrm{Sn}, \mathrm{Pb}$ and $\mathrm{Fe}, \mathrm{Ni}, \mathrm{Sb}, \mathrm{Ag}$, which were measured to observe differences between smelting, manufacturing process and raw material used.

\section{Materials and methods}

\subsection{Samples}

The twenty studied bronze statuettes belong to the Archaeological Museum of Sagunto and are from the archaeological sites of Castillo de Sagunto, Montaña Frontera and Partida de la Vila (Fig. 1), located in Sagunto area (Valencia, Spain). The collection can be appreciated in the Supplementary material section (Annex A).

The studied archaeological bronzes are a set of small size votive statuettes, offered by devotees to the gods in the sanctuaries. The objects represent human figures, mostly masculine. All statuettes have a size between $24 \mathrm{~cm}$ and $6 \mathrm{~cm}$ (Fig. 2).

Eleven studied objects are from the Castillo de Sagunto, corresponding to the statuettes A, B, C, D, E, F, G, H, I, J and K (Annex A). Between them there are four masculine statues in offering position (G, $\mathrm{D}, \mathrm{H}$ and $\mathrm{E}$ ), a representation of a young man and a Bacchus both in offering position (I and A), two figures of a faun ( $\mathrm{J}$ and $\mathrm{K}$ ), one offering to the gods and other with bread and grape in his hands. Also, one figure of a peplophoros, recognized as a possible Venus (Aranegui et al., 2018) wearing peplos (B) and two males without offering (F and C), where the statuette $\mathrm{F}$ was interpreted as a possible Jupiter (Aranegui et al., 2018) were studied. According to the experts, this set cannot be classified as a single manufacture because macroscopically it can be distinguished highly elaborated statuettes than others with a poorest detail being made a stylistic study by Blecht (1989).

Eight statuettes, with very similar manufacture were from the archaeological site of Montaña Frontera, located in the surrounding area of Sagunto, corresponding to L, M, N, O, P, Q, R and S (Annex A). This place is an Ibero-Roman sanctuary and all the figures represent men in offering position, except for the figure $\mathrm{M}$ recognized as a possible Jupiter by Aranegui Gascó et al. (2018). Finally, an additional figure (T) from the archaeological site Partida de la Vila (Annex A) in the city of Sagunto was also studied. This last figure represents a necked male with marked sex in offering position with the peculiarity that it has a pileus (hat) in his head (Aranegui Gascó et al., 2018).

Furthermore, two modern bronzes, elaborated during the 20th century, were used to evaluate the effect of sample geometry in the obtained XRF spectra. Picture of both statues are shown in Fig. 3, where it is possible to see the different measurement positions.

\subsection{Apparatus and methods}

Archaeological and modern bronze objects were directly analysed by X-ray fluorescence. Chemical compositions were obtained with a portable model S1 Titan energy disperse X-ray fluorescence spectrometer from Bruker (Kennewick, Washington, USA), equipped with a rhodium X-ray tube of $50 \mathrm{kV}$ and XFlash ${ }^{\circledast}$ SDD detector. The instrument was controlled by S1RemoteCtrl Metals programme, S1Sync software and ARTAX software from Bruker to obtain spectra and calculate the weight percentage of $\mathrm{Fe}, \mathrm{Ni}, \mathrm{Cu}, \mathrm{Sn}, \mathrm{Sb}, \mathrm{Ag}$ and $\mathrm{Pb}$. A leaded bronze certified sample BAS-CURM50.04-4 was used to evaluate the accuracy of the XRF data obtained. For modern bronzes and leaded bronze certified sample, $\mathrm{Zn}$ results have been also reported.

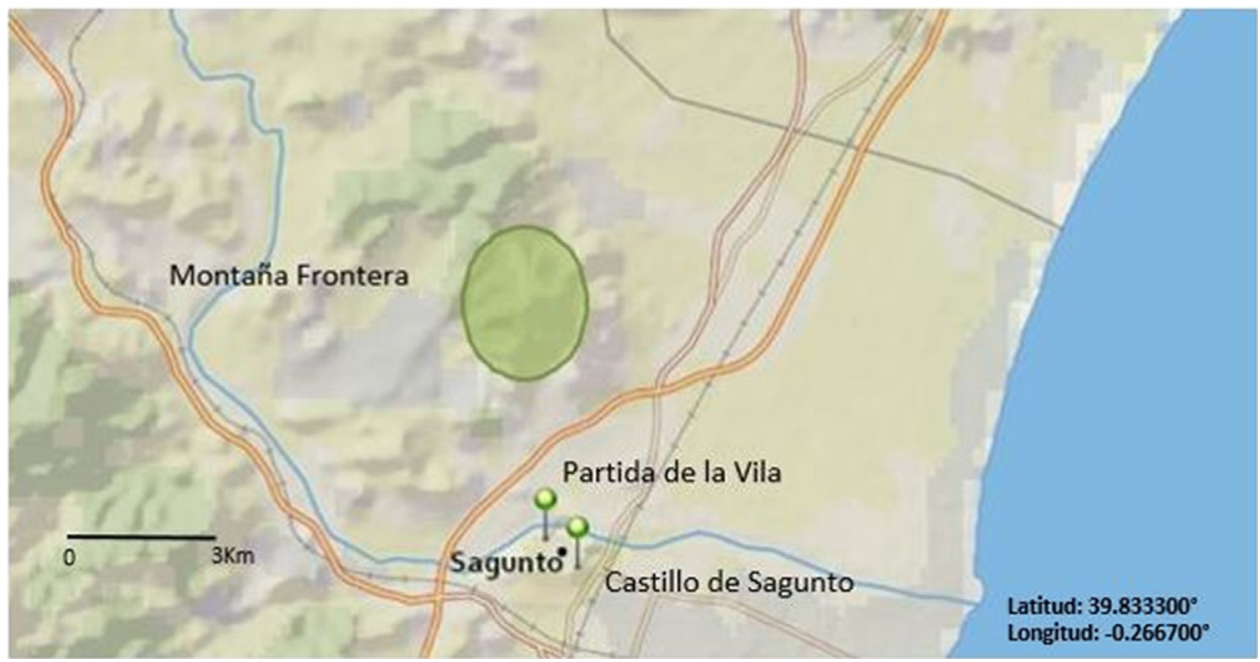

Fig. 1. Localization of the three archaeological sites: Montaña Frontera, Castillo de Sagunto and Partida de la Vila (Valencia, Spain). 

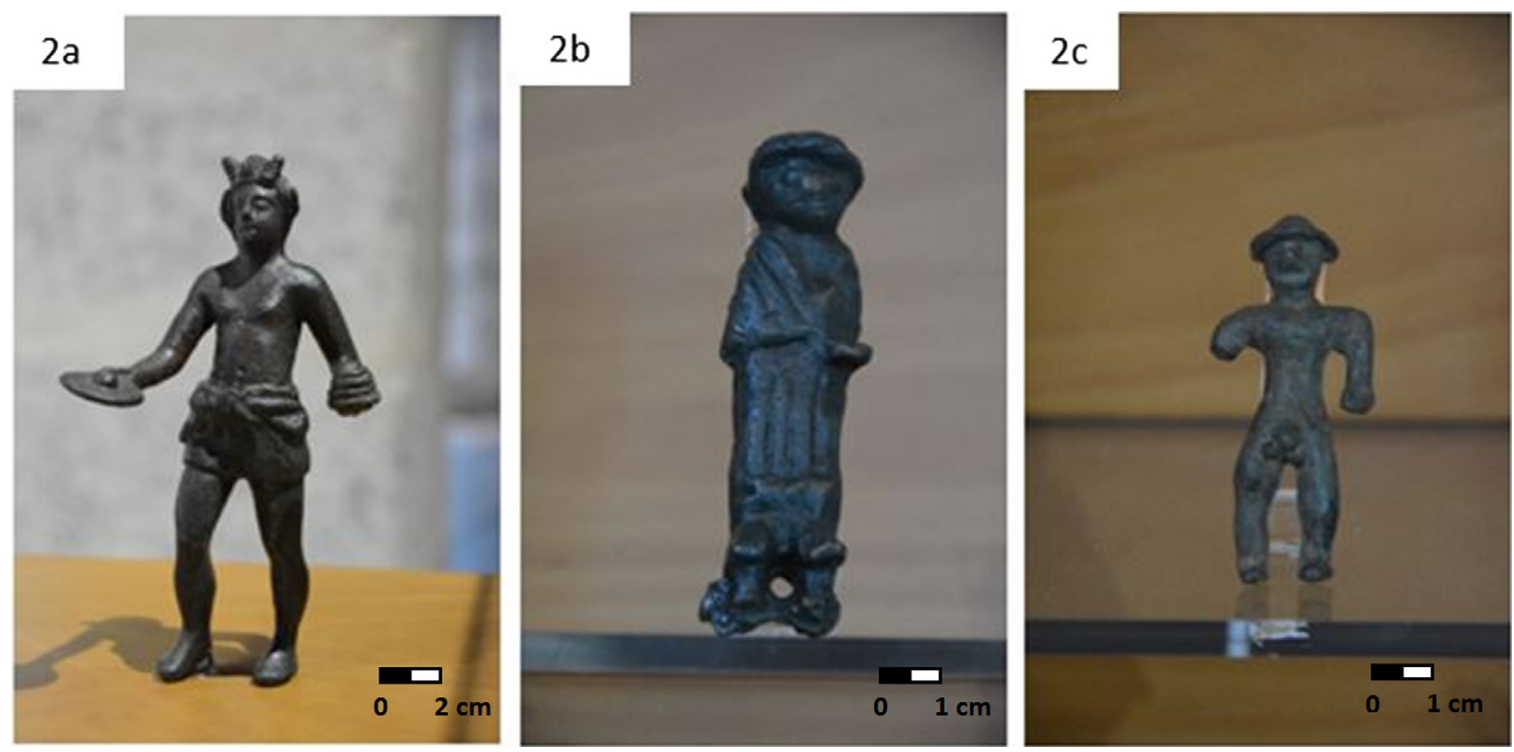

Fig. 2. Representative bronze statues from the three archaeological sites studied: (2a) Castillo de Sagunto; (2b) Montaña Frontera; (2c) Partida de la Vila.

\subsection{Chemometric data treatment}

Data treatment was carried out by using Matlab 8.3.0.532 (R2014a) from Matworks (Natick, MA, USA), using PLS Toolbox 7.5.2 from Eigenvectors Research Inc. (Wenatchee, WA, USA) for Principal Analysis Components (PCA). PCA is a statistical treatment that allows a multivariate analysis based on reduction of variables and provides a projection of objects in a new space related to the minimum number of independent variables suitable to explain an appropriate amount of signal variance. (Ballabio, 2015; Cascant et al., 2017).

Six variables, consisting of $\mathrm{Fe} / \mathrm{Cu}, \mathrm{Pb} / \mathrm{Cu}, \mathrm{Sn} / \mathrm{Cu}, \mathrm{Ag} / \mathrm{Cu}, \mathrm{Ni} / \mathrm{Cu}$, Impurities/Cu. were employed for statistical data treatment. Elements such $\mathrm{Fe}, \mathrm{Cu}, \mathrm{Ni}, \mathrm{Sn}, \mathrm{Sb}, \mathrm{Pb}$ and $\mathrm{Ag}$ are secondary products due to the smelting and manufacturing processes, named in this work as "Impurities" or "contamination" (Trampuž Orela, Drglinb, 2005). To calculate the amount of Impurities the sum of all the elements $(\mathrm{Fe}, \mathrm{Cu}$, $\mathrm{Ni}, \mathrm{Sn}, \mathrm{Sb}, \mathrm{Pb}$ and Ag) obtained by XRF except Cu (Klemenc et al., 1999) were considered. Autoscale as pre-processing and leave one out as cross-validation method were used.

\section{Results and discussion}

\subsection{Previous studies on direct XRF measurements of metal statues}

The analysis of archaeological objects, like the studied ones, must be carried out carefully without provoking any object damage and having just the possibility to run a reduced number of measurements. Therefore, the selection of the measurement mode and an evaluation of data precision and accuracy were carried out employing modern samples (Fig. 3).

\subsubsection{Influence of the measurement mode}

As mentioned above, the analysis of archaeological statues involves the difficulty to obtain a good measurement position between the instrument and the objects, based on the irregularity of the statuettes surface and their size. An erroneous or inconvenient position of the instrument or a movement during the analysis can cause errors in the intensity of the signals and give erroneous metal composition results (Liangquan et al., 1998).

To evaluate the use of the portable device, we carried out a test on modern statues changing the position of the XRF system to simulate difficult measurement conditions in the museum to know how it can cause errors during the final signals. Two measurement modes were tested; full contact between the instrument and the sample surface (FC mode) and incomplete contact between the XRF and the object, due to the irregularities of the sample surface (IC mode). A representation of both modes can be seen in the Fig. 4 .

In Table 1, the average and standard deviation of independent measurements made on the same positions, but with different measurement mode on modern statues, can be observed.
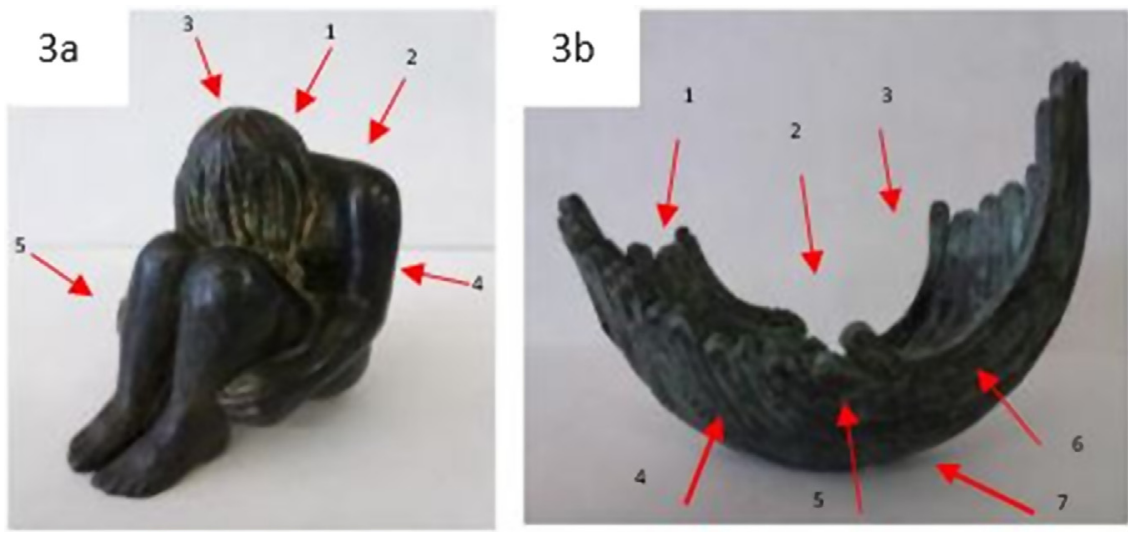

Fig. 3. Modern brass 3a and lead bronze statues $3 \mathrm{~b}$ used to evaluate the reproducibility and precision of XRF data obtained with the portable instrument. 
a)
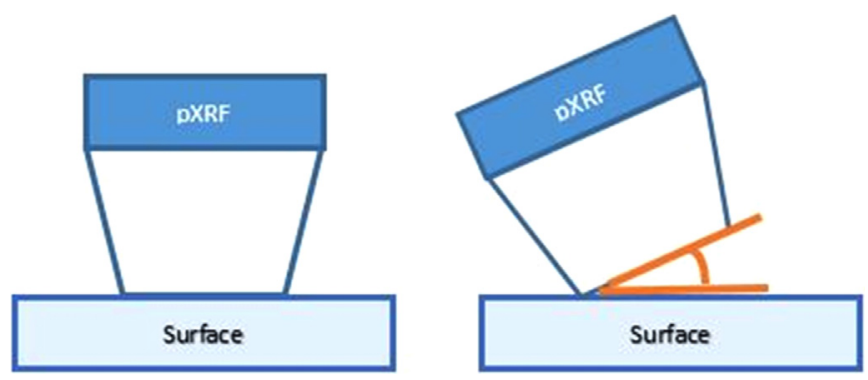

Fig. 4. Measurement: modes: full contact (FC) (a) and incomplete contact (IC) (b).

Observing the chemical data obtained on the modern statuettes, it can be observed that values in FC mode generally are more precise than those corresponding to IC mode. Therefore, an erroneous positioning of XRF system can affect the reproducibility and precision of results, especially for $\mathrm{Ag}$ that presents low concentrations in the statuettes.

An additional mode, of measurement in which the XRF was shaken during the analysis was tested also providing concentration errors and losing of reproducibility in the produced data.

As a conclusion, it can be appreciated that metal composition could be affected by measurement mode and thus, a total contact between the instrument and the sample is desirable. Therefore, we took great care on selecting an area as flat as possible and comfortable for the operator to obtain XRF spectra.

\subsubsection{Homogeneity of the bronze statuettes}

Archaeological statuettes could be heterogeneous with a complex matrix and it may be altered in some areas due to post-depositional processes. Because of that, we conducted a study of the homogeneity of a brass statue sample XRF spectra using to observe the concentration variation of the main elements in different measurement points (Fig. 3a). Table 2 shows the average and standard deviation of the independent measured points illustrated on Fig. 3a using the full contact mode.

Major elements that present a high concentration, like $\mathrm{Cu}$ and $\mathrm{Zn}$ provide similar values in all the positions with a variation coefficient between $4 \%$ and $9 \%$. However, some elements present at concentrations around $0.1 \%$ like $\mathrm{Ni}, \mathrm{Fe}, \mathrm{Sn}$ and $\mathrm{Pb}$ provided different concentration values in different measurement points, which are due to compositional inhomogeneity.

\subsection{Study of the accuracy of the method}

Due to matrix effects, inherent, to the XRF measurements and the complexity of sample matrix, it was not possible to make an external calibration, and thus it was employed a reference sample of leaded bronze measured in the same conditions used for archaeological bronze analysis, to evaluate the accuracy of measurements.

The reference sample (BAS -CURM50.04-4) is an alloy of Cu with Sn and $\mathrm{Pb}$ containing also $\mathrm{Fe}, \mathrm{Ni}, \mathrm{Sb}$ and $\mathrm{Ni}$. The sample was measured in 6 positions. The obtained results are represented in Table 3 .

From data in Table 3, it can be concluded that the average value of each certified element is inside the certified range. On the other hand, the relative standard deviation value (RSD) was around $1-3 \%$ for all the elements, except for $\mathrm{Fe}$ and $\mathrm{Sb}$ with RSD of $6 \%$ at concentration values in the order of $0.5 \%$ and $0.1 \%$. Therefore, portable XRF measurements provide accurate results for the analysis of alloys.

\subsection{Analysis of Ibero-Roman bronze votive statues}

All twenty analysed statues (Annex A) correspond to $\mathrm{Cu}-\mathrm{Sn}-\mathrm{Pb}$ alloys with traces of $\mathrm{Fe}, \mathrm{Ni}, \mathrm{Sb}$ and $\mathrm{Ag}$. Data in Table 4 permits to observe the metal composition one by one of the samples evidencing the great variability of samples from Sagunto Castle and the relative homogeneity of the alloys of Montaña Frontera objects. In all the cases, data were acquired in the full contact (FC) mode, taking several independents measures on the best place and avoiding possible corroded areas. In Fig. 2, the points of measurement are indicated by arrows. When measurements were carried out in the front of the statuettes, it was indicated by an arrow on the right $(\rightarrow)$ and by arrow on the left $(\leftarrow)$ for measurements made in the back of the figures. It must be noticed that due to the significant archaeological value of the objects and their fragility, it was not possible to do more than two replicates and for the statue $\mathrm{T}$ from Partida de la Vila because it extreme fragility only one measurement was possible.

Analysing the data of Table 4 is evident how statues from Montaña Frontera present more homogeneous results than Castillo de Sagunto. The statues that belong to this collection are different between them. In particular, there are three statues that present great differences in the concentration of some elements. Statues $\mathrm{E}$ and I present a high content in Sb (E:2.877\%; I: 2.219\%), $\mathrm{Ni}$ (E: 0.522\%; I: 0.249\%) and $\mathrm{Ag}$ (E: $0.141 \%$; I: $0.300 \%$ ) in comparison with the other statues of the same group and the statue $\mathrm{F}$ present a low content in $\mathrm{Cu}(29.9 \%)$ and high concentration in $\mathrm{Sn}(20.0 \%)$ and $\mathrm{Pb}(49.8 \%)$. These differences could indicate a distinct origin between the statues and the rest of the collection.

Table 1

The effect of the measurement mode on the chemical data of the bronze statue $3 \mathrm{~b}$ by XRF.

\begin{tabular}{|c|c|c|c|c|c|c|c|c|}
\hline & $\mathrm{Fe} \%$ & Ni \% & $\mathrm{Cu} \%$ & Zn \% & Ag \% & Sn \% & Sb \% & $\mathrm{Pb} \%$ \\
\hline 1-FC & $0.094 \pm 0.012$ & $0.499 \pm 0.017$ & $89.3 \pm 0.2$ & $1.57 \pm 0.03$ & $0.0153 \pm 0.0013$ & $5.09 \pm 0.07$ & $0.156 \pm 0.005$ & $3.3 \pm 0.3$ \\
\hline 1-IC & $0.093 \pm 0.011$ & $0.051 \pm 0.02$ & $87.0 \pm 1.4$ & $1.42 \pm 0.03$ & $0.024 \pm 0.006$ & $5.54 \pm 0.13$ & $0.188 \pm 0.003$ & $5.2 \pm 1.3$ \\
\hline 2-FC & $0.0715 \pm 0.0003$ & $0.53 \pm 0.02$ & $91.41 \pm 0.04$ & $1.86 \pm 0.03$ & $0.014 \pm 0.002$ & $4.168 \pm 0.015$ & $0.115 \pm 0.005$ & $1.84 \pm 0.04$ \\
\hline 2-IC & $0.060 \pm 0.003$ & $0.52 \pm 0.03$ & $91.58 \pm 0.07$ & $1.800 \pm 0.005$ & $0.012 \pm 0.006$ & $4.19 \pm 0.07$ & $0.116 \pm 0.016$ & $1.72 \pm 0.04$ \\
\hline 3-FC & $0.054 \pm 0.003$ & $0.509 \pm 0.012$ & $91.86 \pm 0.04$ & $1.932 \pm 0.016$ & $0.008 \pm 0.006$ & $4.09 \pm 0.04$ & $0.104 \pm 0.003$ & $1.45 \pm 0.06$ \\
\hline 3-IC & $0.0471 \pm 0.0016$ & $0.501 \pm 0.009$ & $91.85 \pm 0.08$ & $1.91 \pm 0.03$ & $0.013 \pm 0.002$ & $4.16 \pm 0.05$ & $0.124 \pm 0.014$ & $1.387 \pm 0.009$ \\
\hline 4-FC & $0.070 \pm 0.005$ & $0.489 \pm 0.009$ & $89.82 \pm 0.11$ & $1.725 \pm 0.016$ & $0.015 \pm 0.004$ & $4.41 \pm 0.03$ & $0.138 \pm 0.004$ & $3.34 \pm 0.9$ \\
\hline 4-IC & $0.085 \pm 0.007$ & $0.501 \pm 0.016$ & $88.3 \pm 0.4$ & $1.80 \pm 0.03$ & $0.0182 \pm 0.0013$ & $4.71 \pm 0.03$ & $0.150 \pm 0.008$ & $4.4 \pm 0.4$ \\
\hline 5-FC & $0.074 \pm 0.007$ & $0.526 \pm 0.018$ & $91.02 \pm 0.18$ & $1.99 \pm 0.06$ & $0.0152 \pm 0.0019$ & $3.95 \pm 0.06$ & $0.099 \pm 0.012$ & $2.32 \pm 0.17$ \\
\hline 5- IC & $0.10 \pm 0.03$ & $0.52 \pm 0.03$ & $91.4 \pm 0.3$ & $2.03 \pm 0.05$ & $0.0125 \pm 0.0019$ & $3.8 \pm 0.1$ & $0.095 \pm 0.005$ & $2.1 \pm 0.3$ \\
\hline 6-FC & $0.137 \pm 0.018$ & $0.48 \pm 0.02$ & $86.7 \pm 0.6$ & $1.94 \pm 0.09$ & $0.017 \pm 0.004$ & $5.13 \pm 0.13$ & $0.163 \pm 0.009$ & $5.5 \pm 0.4$ \\
\hline 6-IC & $0.122 \pm 0.011$ & $0.48 \pm 0.03$ & $87.4 \pm 0.3$ & $1.85 \pm 0.05$ & $0.0161 \pm 0.0010$ & $5.00 \pm 0.05$ & $0.152 \pm 0.017$ & $4.9 \pm 0.3$ \\
\hline 7-FC & $0.0564 \pm 0.0011$ & $0.526 \pm 0.014$ & $91.31 \pm 0.02$ & $2.501 \pm 0.008$ & $0.013 \pm 0.003$ & $3.45 \pm 0.02$ & $0.0815 \pm 0.0019$ & $2.07 \pm 0.04$ \\
\hline 7-IC & $0.071 \pm 0.013$ & $0.530 \pm 0.020$ & $91.4 \pm 0.6$ & $2.2 \pm 0.4$ & $0.010 \pm 0.008$ & $3.72 \pm 0.14$ & $0.092 \pm 0.009$ & $2.0 \pm 0.3$ \\
\hline
\end{tabular}


Table 2

Replicated chemical data by XRF on the statuette 3a (Sb $<0.01 \mathrm{wt} \%$; $\mathrm{Ag}<0.01 \mathrm{wt} \%$ ).

\begin{tabular}{|c|c|c|c|c|c|c|}
\hline & $\mathrm{Fe} \%$ & $\mathrm{Ni} \%$ & $\mathrm{Cu} \%$ & $\mathrm{Zn} \%$ & Sn $\%$ & $\mathrm{~Pb} \%$ \\
\hline 1-FC & $0.038 \pm 0.03$ & $0.084 \pm 0.011$ & $77.8 \pm 0.6$ & $21.6 \pm 0.5$ & $0.129 \pm 0.003$ & $0.35 \pm 0.08$ \\
\hline 2-FC & $0.023 \pm 0.005$ & $0.075 \pm 0.003$ & $82.02 \pm 0.14$ & $17.73 \pm 0.14$ & $0.101 \pm 0.007$ & $0.050 \pm 0.004$ \\
\hline 3-FC & $0.022 \pm 0.002$ & $0.08 \pm 0.02$ & $77.4 \pm 0.3$ & $21.5 \pm 0.3$ & $0.168 \pm 0.010$ & $0.86 \pm 0.04$ \\
\hline 4_FC & $0.006 \pm 0.003$ & $0.055 \pm 0.003$ & $77.1 \pm 0.6$ & $22.1 \pm 0.5$ & $0.160 \pm 0.015$ & $0.62 \pm 0.10$ \\
\hline 5_FC & $0.030 \pm 0.004$ & $0.079 \pm 0.012$ & $80.33 \pm 0.03$ & $19.38 \pm 0.05$ & $0.109 \pm 0.017$ & $0.072 \pm 0.006$ \\
\hline mean \pm d.s. & $0.024 \pm 0.012$ & $0.074 \pm 0.011$ & $79 \pm 2$ & $20.5 \pm 1.8$ & $0.13 \pm 0.03$ & $0.4 \pm 0.4$ \\
\hline
\end{tabular}

Table 3

Results obtained for the XRF analysis of a reference sample (BAS -CURM50.044).

\begin{tabular}{lccccccr}
\hline Position & Fe \% & Ni \% & Cu \% & Zn \% & Sn \% & Sb\% & Pb \% \\
\hline $\mathbf{1}$ & 0.095 & 1.08 & 74.35 & 0.665 & 10.96 & 0.438 & 9.71 \\
$\mathbf{2}$ & 0.104 & 1.08 & 76.65 & 0.673 & 11.10 & 0.487 & 10.16 \\
$\mathbf{3}$ & 0.107 & 1.09 & 76.07 & 0.662 & 11.32 & 0.509 & 10.47 \\
$\mathbf{4}$ & 0.104 & 1.11 & 76.36 & 0.652 & 11.40 & 0.515 & 10.07 \\
$\mathbf{5}$ & 0.092 & 1.09 & 74.39 & 0.661 & 11.13 & 0.467 & 9.53 \\
$\mathbf{6}$ & 0.100 & 1.12 & 76.56 & 0.657 & 11.26 & 0.491 & 10.06 \\
Mean & 0.100 & 1.094 & 75.7 & 0.661 & 11.20 & 0.48 & 10.0 \\
s.d. & 0.006 & 0.014 & 1.1 & 0.007 & 0.10 & 0.03 & 0.3 \\
RSD \% & 5.901 & 1.285 & 1.4 & 1.082 & 1.43 & 5.88 & 3.3 \\
MRC. Mean & 0.100 & 1.10 & 76.11 & 0.66 & 11.30 & 0.50 & 9.94 \\
MRC. s.d. & 0.005 & 0.01 & 0.03 & 0.01 & 0.06 & 0.01 & 0.08 \\
\hline
\end{tabular}

\subsection{Classification of archaeological bronze statuettes}

Principal Components Analysis (PCA) was applied to the whole set of archaeological bronzes using as variables $\mathrm{Fe} / \mathrm{Cu}, \mathrm{Pb} / \mathrm{Cu}, \mathrm{Sn} / \mathrm{Cu}, \mathrm{Ag}$ / $\mathrm{Cu}, \mathrm{Ni} / \mathrm{Cu}$ and Impurities/Cu. Fig. 5, shows the scores plot in which it was reported the relative position of the twenty statues of bronze. The PCA was carried out taking into account principal components PC1 that explains $53.87 \%$ of the data variance and PC2 (21.57\%), consequently the first two PCs explain the main part of the variance of the data (75.44\%). PC1, as it can be seen in the loadings plot of Fig. 5, is mainly influenced by the relations $\mathrm{Sn} / \mathrm{Cu}$, Impurities/Cu, $\mathrm{Pb} / \mathrm{Cu}$ and $\mathrm{Fe} / \mathrm{Cu}$. PC2 strongly depends on relations $\mathrm{Ag} / \mathrm{Cu}$ and $\mathrm{Ni} / \mathrm{Cu}$. Samples are classified according to the archaeological site Castillo de Sagunto, Montaña Frontera and Partida de la Vila. Data used for the elaboration of the PCA are available in the Table 4.

Analysing the PCA model it is perfectly visible that the statues from the archaeological sites Castillo de Sagunto and Montaña Frontera are separated into distinct groups. These groups are mainly separeted in PC1 direction.

The presence of a greater or lesser extent of elements like $\mathrm{Sn}, \mathrm{Fe}, \mathrm{Pb}$, $\mathrm{Ni}$ and $\mathrm{Ag}$ can give information about smelting and manufacturing process and the used raw material. This is the case of the content of Fe in relation to $\mathrm{Cu}$ that can be indicative of the evolution during the smelting process becoming sophisticated with the development of the technique (Craddock and Meeks, 1987; Klemenc et al., 1999). This increase of Fe could be due to an incorporation of iron minerals as slags formed in elaborated smelting processes and changes in smelting technology, may also reflected in the surviving field evidence of metal production (Craddock and Meeks, 1987; Klemenc et al., 1999). The presence of smelting process contamination in the bronze is also related with a profitable multi-stage smelting process where used low grade minerals make necessary the improvement of the smelting technique (Craddock and Meeks, 1987; Klemenc et al., 1999). The increase of Pb and $\mathrm{Sn}$ with respect to $\mathrm{Cu}$ can be also showed in the statues from modern period where copper alloys were better monitored and controlled (Karydas, 2007). On the other hand, the ratios of $\mathrm{Ag} / \mathrm{Cu}$ and Ni/ $\mathrm{Cu}$ are related with differences in raw material (Tylecote et al., 1977).

The variables that influence the separations between the samples from Castillo de Sagunto and Montaña Frontera are mainly $\mathrm{Sn} / \mathrm{Cu}, \mathrm{Pb} /$ $\mathrm{Cu}$, Impurities/ $\mathrm{Cu}$ and $\mathrm{Fe} / \mathrm{Cu}$. The results suggest that the difference between the two groups is due to the smelting and manufacturing process as the high content of Impurities, $\mathrm{Sn}, \mathrm{Pb}$ and $\mathrm{Fe}$ indicates an evolution in the process (Craddock and Meeks, 1987; Klemenc et al., 1999; Karydas, 2007). The high content of Impurities, Sn, Pb and Fe in the statues from Montaña Frontera shows that these statues were produced later than the statues from Castillo de Sagunto that were from an earlier period (Craddock and Meeks, 1987; Klemenc et al., 1999; Karydas, 2007). The distribution of the statues in the PCA suggests proximity in the manufacturing period between some statues from the three groups Castillo de Sagunto, Montaña Frontera and Partida de la

Table 4

Average chemical composition of the analysed bronze statuettes (wt $\%$ ).

\begin{tabular}{|c|c|c|c|c|c|c|c|c|}
\hline Archaeological site & Measure & $\mathrm{Fe} \%$ & $\mathrm{Ni} \%$ & $\mathrm{Cu} \%$ & $\mathrm{Ag} \%$ & Sn $\%$ & $\mathrm{Sb} \%$ & $\mathrm{~Pb} \%$ \\
\hline Castillo de Sagunto & A & 0.181 & 0.098 & 70.7 & 0.052 & 6.9 & 0.124 & 22.0 \\
\hline Castillo de Sagunto & $\mathrm{B}$ & 0.203 & 0.111 & 83.8 & 0.016 & 11.6 & 0.026 & 4.3 \\
\hline Castillo de Sagunto & $\mathrm{C}$ & 0.250 & 0.111 & 74.2 & 0.069 & 7.2 & 0.187 & 18.0 \\
\hline Castillo de Sagunto & $\mathrm{D}$ & 0.226 & 0.065 & 49.4 & 0.028 & 5.5 & 0.101 & 44.7 \\
\hline Castillo de Sagunto & $\mathrm{E}$ & 0.213 & 0.522 & 60.3 & 0.141 & 5.0 & 2.877 & 30.9 \\
\hline Castillo de Sagunto & $\mathrm{F}$ & 0.176 & 0.106 & 29.9 & 0.036 & 20.0 & 0.026 & 49.8 \\
\hline Castillo de Sagunto & G & 0.130 & 0.100 & 77.6 & 0.069 & 1.9 & 0.212 & 20.0 \\
\hline Castillo de Sagunto & $\mathrm{H}$ & 0.207 & 0.065 & 57.2 & 0.023 & 7.6 & 0.072 & 34.8 \\
\hline Castillo de Sagunto & I & 0.157 & 0.249 & 77.7 & 0.300 & 9.1 & 2.219 & 10.3 \\
\hline Castillo de Sagunto & $\mathrm{J}$ & 0.229 & 0.060 & 56.1 & 0.028 & 15.3 & 0.042 & 28.2 \\
\hline Castillo de Sagunto & $\mathrm{K}$ & 0.159 & 0.085 & 57.3 & 0.058 & 10.1 & 0.170 & 32.2 \\
\hline Montaña Frontera & $\mathrm{L}$ & 0.329 & 0.162 & 47.7 & 0.094 & 18.2 & 0.352 & 33.1 \\
\hline Montaña Frontera & M & 0.182 & 0.134 & 49.9 & 0.146 & 14.3 & 0.415 & 35.0 \\
\hline Montaña Frontera & $\mathrm{N}$ & 0.662 & 0.069 & 36.1 & 0.090 & 22.6 & 0.215 & 40.3 \\
\hline Montaña Frontera & $\mathrm{O}$ & 1.026 & 0.127 & 43.9 & 0.078 & 24.5 & 0.251 & 30.1 \\
\hline Montaña Frontera & $\mathrm{P}$ & 0.128 & 0.098 & 50.7 & 0.142 & 11.9 & 0.383 & 36.6 \\
\hline Montaña Frontera & $\mathrm{Q}$ & 0.242 & 0.139 & 47.6 & 0.096 & 23.0 & 0.491 & 28.4 \\
\hline Montaña Frontera & $\mathrm{R}$ & 0.312 & 0.127 & 42.0 & 0.219 & 22.6 & 0.215 & 30.5 \\
\hline Montaña Frontera & $\mathrm{S}$ & 0.615 & 0.086 & 47.8 & 0.126 & 17.7 & 0.293 & 33.4 \\
\hline Partida de la Vila & $\mathrm{T}$ & 0.734 & 0.087 & 54.2 & 0.038 & 12.7 & 0.128 & 32.1 \\
\hline
\end{tabular}



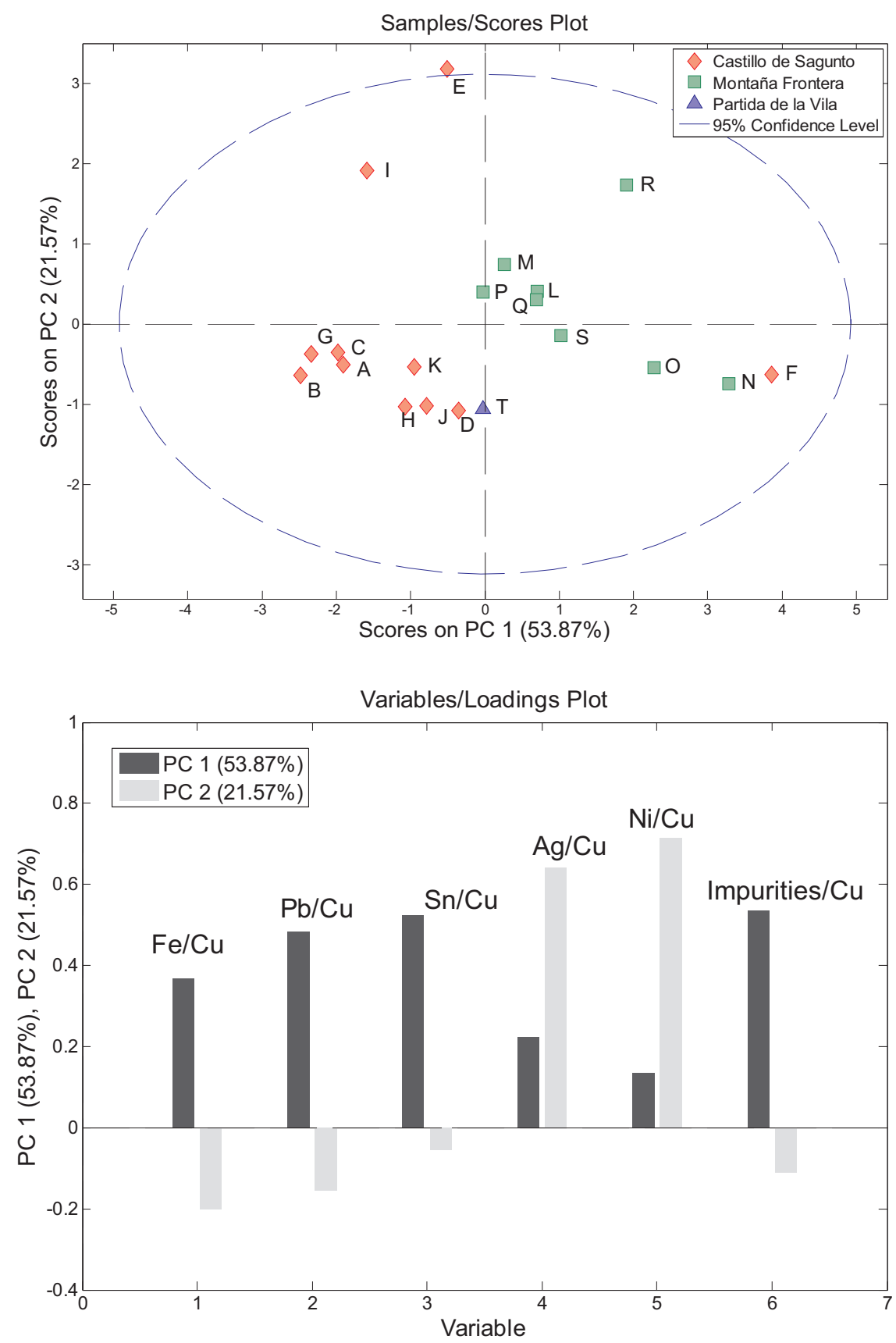

Fig. 5. Score plot (top) and loadings plot (down) of the archaeological samples studied.

Vila, the statues are T, P, M, H, D, L, J, Q, S and K. This similarity could correspond to a chronological overlap between the production of the above mentioned statues from Castillo de Sagunto and those from Montaña Frontera. A macroscopic, typological study confirmed the result obtained, classifying statuettes from Castillo de Sagunto as Tardorepublican period (II-I B.C.) and those from Montaña Frontera between Tardo-Republican and Imperial Period (II B.C. - IA.C.). In relation to the source materials there is no evidence that the objects were elaborated with a different raw material.

However for figures F, E and I of Castillo de Sagunto (Annex A) a deeper discussion needs to be developed. Figure I and $\mathrm{E}$ separate in the direction PC2 present a high content of Ag and Ni respect to the other samples of Castillo de Sagunto. The high levels in these elements indicate differences in the raw material used during the manufacturing process (Tylecote et al., 1977). Respect to figure F, the fact that high Impurities, $\mathrm{Pb}, \mathrm{Fe}$ and $\mathrm{Sn}$ concentrations are detected, compared to the rest of objects from Castillo de Sagunto, could indicate a later period of elaboration respect the other statues of same collection (Craddock and Meeks, 1987; Klemenc et al., 1999; Karydas, 2007). An other possible hypothesis could be related to the fact that $\mathrm{F}$ corresponds to a statuette probably representing Jupiter, and may raw material from no local sources have been employed to make this figure. Furthermore should be highlighted that purer raw materials have been employed to make other statuettes representing gods as the figure A (Bacchus) and B (Venus).

\subsection{Comparative study with an Iberian votive statues collection}

A comparative study was made between the Sagunto collection and a collection of thirty-two Iberian votive figurines from the Museum of Prehistory of Valencia also measured by EDXRF (Roldán García and Vives-Ferrándiz Sánchez, 2018). This second collection comes from the Sanctuaries of Collado de los Jardines and Altos del Sotillo in the region 


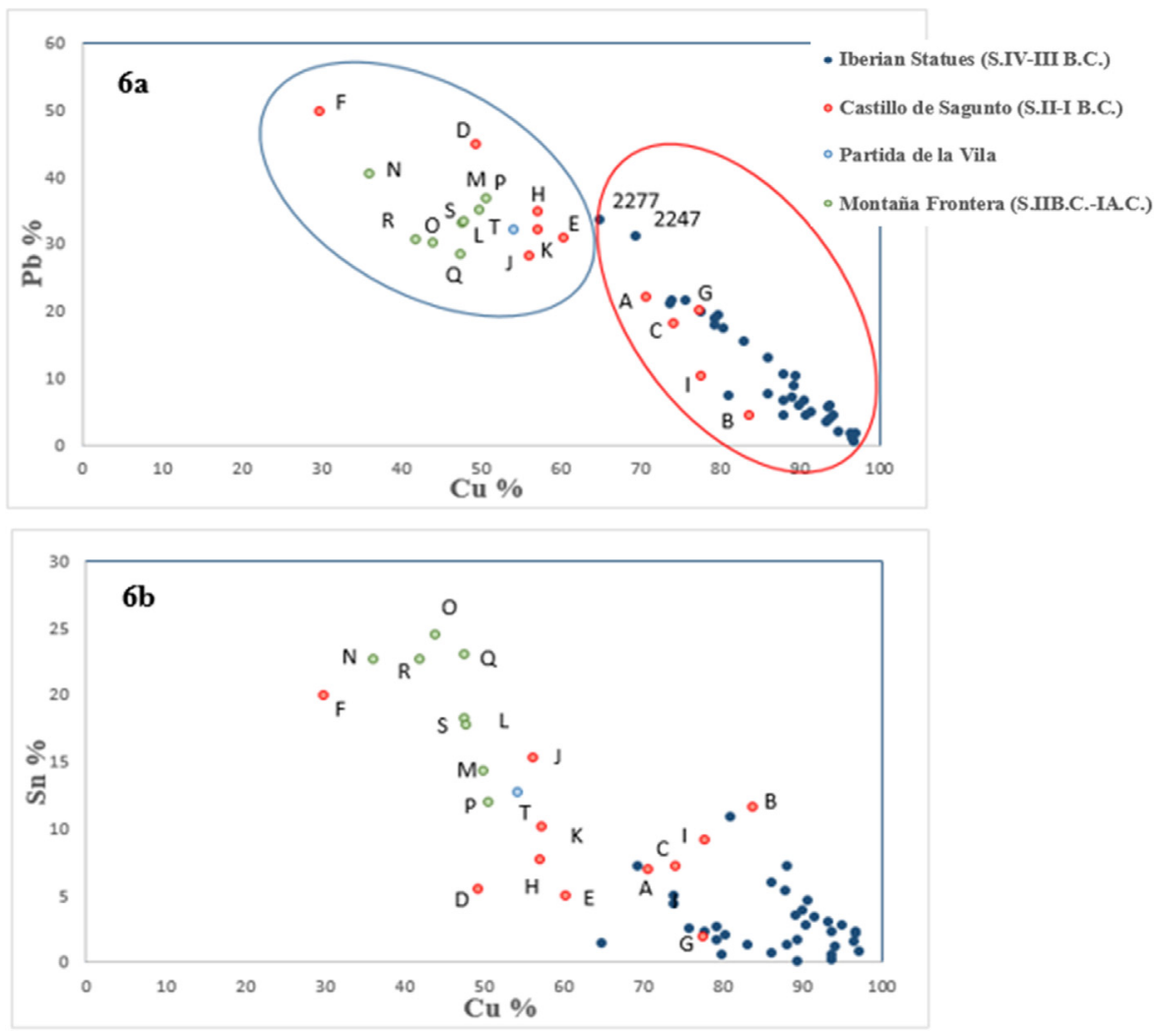

Fig. 6. Correlation $\mathrm{Pb}-\mathrm{Cu} \%$ (6a) and $\mathrm{Sn}-\mathrm{Cu} \%$ to compare Castillo de Sagunto, Partida de la Vila and Montaña Frontera statues to the Iberian statues.

of Jaen (Spain) and are dated from the century IV-III B.C. The results obtained by Roldán García and Vives-Ferrándiz Sánchez (2018) of the measured $\mathrm{Pb}, \mathrm{Sn}$ and $\mathrm{Cu}$ concentrations were cross-referenced with our produced data.

Fig. 6 shows the variation of $\mathrm{Pb} \%,(6 \mathrm{a})$ and $\mathrm{Sn} \%(6 \mathrm{~b})$ as a function of $\mathrm{Cu} \%$ for the whole set of studied statues and the Iberian ones. It can be seen that statues can be classified based on the technological advances of the manufacturing processes that reveal the increasing amount of $\mathrm{Sn}$ and $\mathrm{Pb}$ (Karydas, 2007).

The statues from Partida de la Vila and Montaña Frontera show the greatest values of $\mathrm{Pb}$ and $\mathrm{Sn}$ that correspond with the late period statues. On the other hand, statues from Castillo de Sagunto present intermediate values, where the statues B, I, C, G and A are placed close to the earlier period Iberian statues based on low contents of these elements as compared to the other statues from Castillo de Sagunto (D, E, $\mathrm{H}, \mathrm{K}$, and $\mathrm{J}$ ). This fact corresponds with the result of the PCA where the statues B, I, C, G and A are plotted farer from the statues from Montaña Frontera. On the other hand, Iberian statues show the lowest values of $\mathrm{Sn}$ and $\mathrm{Pb}$ respect to $\mathrm{Cu}$, it confirms that these statues belong to an earlier period than the statues from Sagunto. An exception can be seen between the Iberian statues in the correlation $\mathrm{Pb}-\mathrm{Cu}$. The higher value of $\mathrm{Pb}$ respect to $\mathrm{Cu}$ for samples 2177 (adult woman) and 2247 (fibula) set them near the statues from Castillo de Sagunto and Montaña Frontera. Unfortunately we cannot explain the reason of this fact.

This comparative study was made to corroborate the age of the statues and verify the utility of the ratios employed for the chronology determination.

These results are in line and enhance the conclusions obtained in the PCA highlighting that an increment of the $\mathrm{Sn}$ and $\mathrm{Pb}$ respect to $\mathrm{Cu}$ is directly related with a modern process of manufacturing. However the hypothesis of a purer material employed for gods representations must be taken into account for figures such A (Bacchus) and B (Venus). Statuette F (Jupiter) is also oppositely related to the mentioned figures and may raw material from no local sources have been employed to represent a God.

\section{Conclusion}

The use of dispersive energy X-ray fluorescence allowed to successfully determine, for the first time, the metal composition of the twenty archaeological bronze statuettes of Sagunto, despite the limitations to carry out measurements on archaeological valuable and fragile objects. Through multivariate analysis made by Principal Components Analysis (PCA) employing $\mathrm{Fe} / \mathrm{Cu}, \mathrm{Sn} / \mathrm{Cu}, \mathrm{Pb} / \mathrm{Cu}$ and Impurities/Cu as variables we were able to differentiate the statues according to their smelting and manufacturing processes. Our established methodological approach and obtained results confirm that the statues from the archaeological site Castillo de Sagunto were manufactured earlier than the statues from Montaña Frontera and Partida de la Vila. The utility of the ratios $\mathrm{Sn} / \mathrm{Cu}$ and $\mathrm{Pb} / \mathrm{Cu}$ was evaluated throughout a comparative study between the statues from Sagunto and the collection from the Museum of Prehistory of Valencia that confirm and enhance the results obtained. Furthermore, using the mentioned ratios may it was possible to develop hypothesis about the statuettes representing gods, being made by no local raw materials $(F)$ or employing purer raw materials (A and B)

\section{Acknowledgements}

Authors acknowledge the financial support of the Ministerio de Economía y Competitividad-Feder (Project CTQ 2014-52841-P and Project CTQ 2012-38635).

The authors would like to thanks Matías Calvo conservator of the Archaeological Museum of Sagunto which has contributed to the realization of this study. 


\section{Declarations of interest}

None.

\section{Appendix A. Supporting information}

Supplementary data associated with this article can be found in the online version at doi:10.1016/j.radphyschem.2019.02.031

\section{References}

Aranegui Gascó, C., Izquierdo Peraile, I., Hernández Hervás, E., Graells I Fabregat, R., 2018. La romanización de los bronces ibéricos: el conjunto de Muntanya Frontera de Sagunto (Valencia). Bronces Ibéricos. UNA Historia por contar Libro homenaje al Prof. Gérard Nicolini, pp. 455-490.

Bachler, M.C., Bišćan, M., Kregarb, Z., Badovinac, I.J., Dobrinić, J., Milošević, S., 2016 Analysis of antique bronze coins by laser induced breakdown spectroscopy and multivariate analysis. Spectrochim. Acta Part B 123, 163-170.

Baldassarri, M., Cavalcanti, G.H., Ferretti, M., Gorghinian, A., Grifoni, E., Legnaioli, S., Lorenzetti, G., Pagnotta, S., Marras, L., Violano, E., Lezzerini, M., Palleschi, V., 2014. X-ray fluorescence analysis of XII-XIV century Italian gold coins. J. Archaeol. Hindawi Publ. Corp. 1, 1-20. https://doi.org/10.1155/2014/519218.

Ballabio, D., 2015. A MATLAB toolbox for principal component analysis and unsupervised exploration of data structure. Chemom. Intell. Lab. Syst. 149, 1-9.

Blecht, M., 1989. "Republikanische Bronzestatuetten aus Sagunt", homenatge.A. Chabret 1888-1988. València 43-91.

Cascant, M.M., Rubio, S., Gallello, G., Pastor, A., Garrigues, S., De La Guardia, M., 2017. Burned bones forensic investigations employing near infrared spectroscopy. Vib. Spectrosc. 90, 21-30.

Craddock, P.T., Meeks, N.D., 1987. Iron in ancient copper. Archaeometry 29 (2), 187-204.

Dungworth, D., 1997. Roman copper alloys: analysis of artefacts from Northern Britain. J. Archaeol. Sci. 24, 901-910.

Ferretti, M., Cristoforetti, G., Legnaioli, S., Palleschi, V., Salvetti, A., Tognoni, E., Console, E., Palaia, P., 2007. In situ study of the Porticello bronzes by portable X-ray fluorescence and laser-induced breakdown spectroscopy. Spectrochim. Acta Part B 62, $1512-1518$.

Forster, N., Grave, P., Vickery, N., Kealhofer, L., 2011. Non-destructive analysis using PXRF: methodology and application to archaeological ceramics. X-Ray Spectrom. 40, 389-398.

Gallello, G., Orozco, T., Pastor, A., De La Guardia, M., Bernabeu, J., 2016. Regional provenance of dolerite prehistoric objects through mineral analysis. Microchem. J. 124, 167-174.

Grau Mira, I., Gallello, G., 2017. Assessing the territorial influence of an Iberian worship site. The chemical characterisation of the terracotta from the iron age sanctuary of La Serreta. J. Archaeol. Sci.: Rep. 13, 142-150.

Grave, P., Attenbrow, V., Sutherland, L., Pogson, R., Forster, N., 2012. Non-destructive pXRF of mafic stone tools. J. Archaeol. Sci. 39, 1674-1686.

Hunt, A.M.W., Speakman, R.J., 2015. Portable XRF analysis of archaeological sediments and ceramics. J. Archaeol. Sci. 53, 626-638.

Karydas, A.G., 2007. Application of a portable XRF spectrometer for the non-invasive analysis of museum metal artefacts. Ann. Chim. 97, 419-432.

Klemenc, S., Budič, B., Zupan, J., 1999. Statistical evaluation of data obtained by inductively coupled plasma atomic emission spectrometry (ICP-AES) for archaeolo gical copper ingots. Anal. Chim. Acta 389, 141-150.

Liangquan, G., Ye, Z., Yeshun, C., Wangchang, L., 1998. The surface geometrical structure effect in in situ X-ray fluorescence analysis of rocks. Appl. Radiat. Isot. 49 (12), 1713-1720.

Navas, M., Garciá Asuero, A., Jimenez, A., 2016. A review of energy dispersive X-ray fluorescence (EDXRF) as an analytical tool in numismatic studies. Appl. Spectrosc. 70, 207-221.

Neff, D., Reguer, S., Dillmann, P., 2013. Analytical techniques for the study of corrosion of metallic heritage artefacts: from micrometer to nanometer scales. In: Corrosion and Conservation of Cultural Heritage Metallic Artefacts. Elsevier, pp. 55-81.

Robbiola, L., Blengino, J.M., Fiaud, C., 1998. Morphology and mechanisms of formation of natural patinas on archaeological Cu-Sn alloys. Corros. Sci. 40 (12), 2083-2111.

Roldán García, C., Vives-Ferrándiz Sánchez, J., 2018. A compositional analysis byenergy dispersive X-ray fluorescence of Iberian copper-alloy votive figurines from southern Spain (fourth-third centuries BC). X-Ray Spectrom. 47, 441-449. https://doi.org/10. $1002 / x r s .2972$

Sáez, R., Nocete, F., Nieto, J.M., Capitán, M.A., Rovira, S., 2003. The extractive metallurgy of copper from Cabezo Juré, Huelva, Spain: chemical and mineralogical study of slags dated to the third millennium B.C. Can. Mineral. 41, 627-638.

Scott, D., 2013. The use of metallographic and metallurgical investigation methods in the preservation of metallic heritage artefacts. In: Corrosion and Conservation of Cultural Heritage Metallic Artefacts. Elsevier, pp. 82-99.

Schiavon, N., Celauro, A., Manso, M., Brunetti, A., Susanna, F., 2013. Iron-age bronze statuettes in Southern Portugal: combining archaeological data with EDXRF and BSEM + EDS to assess provenance and production technology. Appl. Phys. A: Mater. Sci. Process. 113 (4), 865-875. https://doi.org/10.1007/s00339-013-7747-7.

Schiavon, N., De Palmas, A., Bulla, C., Piga, G., Brunetti, A., 2016. An energy-dispersive $\mathrm{X}$-ray fluorescence spectrometry and Monte Carlo simulation study of iron-age Nuragic small bronzes ("Navicelle") from Sardinia, Italy. Spectrochim. Acta Part B 123, 42-46.

Scuotto, M., Bassi, C., Lezzerini, M., Grifoni, E., Legnaioli, S., Lorenzetti, G., Pagnotta, S., Palleschi, V., 2014. X-ray fluorescence analysis on a group of coins from the ancient Roman city of Tridentum (Trento, Italy). X-Ray Spectrom. 43, 370-374.

Sorrentino, G., Giuntoli, S., Lezzerini, M., Grifoni, E., Legnaioli, S., Lorenzetti, G., Pagnotta, S., Palleschi, V., 2015. Classification studies on Etruscan archaeological copper-based alloy findings from the Necropolis of 'Pratino' in Tuscania. J. Appl. Laser Spectrosc. 2, 15-19.

Smith, A., Botha, H., De Beer, F.C., Ferg, E., 2011. The examination, analysis and conservation of a bronze Egyptian Horus statuette. Nucl. Inst. Methods Phys. Res. A 651, $221-228$.

Speakman, R.J., Shackley, M.S., 2013. Silo science and portable XRF in archaeology: a response to Frahm. J. Archaeol. Sci. 40, 1435-1443.

Trampuž Orela, N., Drglinb, T., 2005. ICP-AES comparative study of some Late bronze age hoards: evidence for low impurity bronzes in the eastern Alps. Nucl. Instrum. Methods Phys. Res. Sect. B: Beam Interact. Mater. At. 239, 44-50.

Tylecote, R.F., Ghaznavia, H.A., Boydell, P.J., 1977. Partitioning of trace elements between the ores, fluxes, slags and metal during the smelting of copper. J. Archaeol. Sci. 4, 305-333.

Vasiliev, A., Kovalchuk, M., Yatsishina, E., 2016. Electron microscopy methods in studies of cultural heritage sites. Crystallogr. Rep. 61 (6), 873-885. 